\title{
Use of cardiac biomarkers in neonatology
}

\author{
Daniel C. Vijlbrief', Manon J.N.L. Benders' ${ }^{1}$ Hans Kemperman'², Frank van Bel' and Willem B. de Vries'
}

Cardiac biomarkers are used to identify cardiac disease in term and preterm infants. This review discusses the roles of natriuretic peptides and cardiac troponins. Natriuretic peptide levels are elevated during atrial strain (atrial natriuretic peptide (ANP)) or ventricular strain (B-type natriuretic peptide (BNP)). These markers correspond well with cardiac function and can be used to identify cardiac disease. Cardiac troponins are used to assess cardiomyocyte compromise. Affected cardiomyocytes release troponin into the bloodstream, resulting in elevated levels of cardiac troponin. Cardiac biomarkers are being increasingly incorporated into clinical trials as indicators of myocardial strain. Furthermore, cardiac biomarkers can possibly be used to guide therapy and improve outcome. Natriuretic peptides and cardiac troponins are potential tools in the diagnosis and treatment of neonatal disease that is complicated by circulatory compromise. However, clear reference ranges need to be set and validation needs to be carried out in a population of interest.

Carding ardiac biomarkers provide a view into the structure and functioning of the heart in newborn infants. Several of these biomarkers are already in clinical use, and others are under investigation. The most commonly used cardiac biomarkers are the natriuretic peptides and troponins. The former relate to cardiac stress and ventricular strain, whereas the latter signal cardiomyocyte compromise $(1,2)$. The markers are used in clinical trials to provide insight into the extent of compromise in the functioning of the newborn's heart (3).

The aim of this review is to discuss the clinical indications of the most relevant cardiac biomarkers. The use of these biomarkers in the prediction of short- and long-term outcomes will also be discussed $(4,5)$. Finally, we evaluate the status regarding the use of cardiac biomarkers in determining treatment protocols and the use of these biomarkers in future clinical trials. This review focuses on the use of biomarkers in newborns; congenital heart defects and surgery are discussed only marginally.

\section{CARDIAC BIOMARKERS}

\section{Natriuretic Peptides}

Since electron microscopy first revealed secretory granules in atrial cells containing atrial natriuretic peptide (ANP), four natriuretic peptides have been described; natriuretic peptides A,
$\mathrm{B}, \mathrm{C}$, and D (6). All natriuretic peptides have aminoacid ringshaped structures, but they differ in their modes of action. The function of ANP was discovered after atrial extracts were infused into rats. De Bolt et al. found that massive diuresis and natriuresis occurred (7). This observation started research into the role of endocrines in the heart, and eventually led to the discovery of other natriuretic peptides, primarily B-type natriuretic peptide (BNP). Natriuretic peptide C and Dendroaspis natriuretic peptide have also been identified, but their clinical value has yet to be evaluated $(8,9)$. In the past two decades, much research has been done to clarify the functions of natriuretic peptides. ANP is released from the atrial myocardium in response to stretching of the atrial wall. BNP is released from the ventricular myocardium in response to stretching of the ventricular wall (10). These properties make natriuretic peptides attractive in the identification of congestive heart failure. Given that the serum half-life of BNP is longer than that of ANP, and that the former more accurately reflects cardiac function, BNP or the inactive $\mathrm{N}$-terminal fragment of BNP (NT-proBNP) is generally preferred as a cardiac biomarker $(11,12)$. When their application in adult medicine was found to show promise, research began to be directed toward the potential use of natriuretic peptides in neonatal medicine. Hölmstrom et al. found a strong correlation between BNP and NT-proBNP; therefore both are considered to be useable depending on local availability (13). Because NT-proBNP is excreted primarily by the kidney, its use depends on renal function (14). BNP and NT-proBNP are good indicators of ventricular functioning and can be used in the diagnosis of relevant diseases, thereby reducing the need for echocardiography (2).

Normal values. Efforts have been made to provide normative values for term and preterm infants $(6,15)$. BNP and NT-proBNP concentrations rise at birth in normal healthy infants, level off at 3-4 d, and then fall steadily to stable but low levels in infancy $(12,16)$. In several studies, the method of delivery of the newborn did not influence natriuretic peptide levels $(17,18)$. However, Fortunato et al. reported that NT-proBNP was significantly higher in infants delivered by elective cesarean section than in infants delivered after spontaneous birth. In fact, NT-proBNP levels were higher after elective cesarean section than after a cesarean section carried out during active labor, suggesting that the decrease in NT-proBNP levels is probably attributable to labor rather than to the mode of delivery (19). 
After birth, the right ventricle of the neonate is exposed to high pulmonary pressure. The high levels of BNP provide vasodilatation and diuresis, thereby playing a crucial role in hemodynamic adaptation after birth. The fall in pulmonary pressure due to lung expansion, and the onset of diuresis with renal maturation explain the subsequent fall in BNP levels. Variability between different assays and local practices makes it difficult to carry out comparisons among studies involving natriuretic peptides (6). It is recommended that reference values relating to control patients be used in order to make evaluation possible. Although this may be feasible for research studies, it is very impractical in a clinical setting. The changes involved while adapting to extrauterine life further complicate the use of natriuretic peptides as biomarkers. However, an increase in use, an emphasis on the need to generate normal ranges, standardization of methods of measurement, and an increase in commercial availability, possibly in combination with a "point-of-care" facility, will help to overcome these hurdles (20). In future studies that address the clinical use of natriuretic peptides in neonatology, authors should emphasize the changes in natriuretic peptide levels rather than specific levels per se. This approach would make the biomarkers more accessible for clinical use.

\section{Cardiac Troponins}

For detection of compromised myocardial functioning, many biomarkers have been proposed. Creatine kinase-MB and the cardiac troponins I and $\mathrm{T}$ (cTnI and cTnT) are the ones that are most in use. Creatine kinase-MB levels are elevated in newborns after perinatal and neonatal hypoxia-ischemia, but this elevation is not specific enough to be of clinical value $(21,22)$. Troponin is an inhibitory protein complex located on the actin filament in all striated muscles, and consists of three subunits $\mathrm{T}, \mathrm{C}$, and $\mathrm{I}$. There is conclusive preclinical and clinical evidence in adult medicine to show that cardiac troponin is reliable in assessing cardiomyocyte injury (23). cTnT and cTnI are used to detect myocardial compromise in the newborn, although the use of cTnI as a marker in newborns is debated. Although some issues have been resolved, further research is necessary before cTnI can be used in clinical practice (24-30).

Normal values. The levels of cTnT in healthy term and preterm infants rise during the first few days of life, peaking on day 3 . The reason for this rise is unclear. Several hypotheses have been proposed. It could be that the perinatal period causes minimal myocardial compromise; alternatively, the rise may be a result of perinatal cardiovascular remodeling in the course of adapting to extrauterine life, possibly influenced by respiratory compromise $(31,32)$. No relationship was found between elevated troponin levels and the method of delivery $(33,34)$. Reference values are available, but, especially in the case of cTnI, these are related to the type of assay used (31). As discussed earlier, this is an important limitation for routine clinical use.

\section{Clinical Indications}

Growth restriction and antenatal stress. Placental dysfunction leading to growth restriction and preeclampsia is a common and serious complication during pregnancy. Placental dysfunction leads to hypoxemia and nutritional deficiency with inevitable effects on myocytes and cardiac function. Several studies found elevated cord blood BNP or NT-proBNP to be associated with antenatal stress and intrauterine growth restriction. Elevated BNP levels are found in full-term and preterm infants experiencing placental dysfunction in utero. Cardiac dysfunction was related to the progression of fetal compromise $(35,36)$. No additional effect of maternal preeclampsia on peripartum cardiac dysfunction was found (37). Prepartum evaluation of the pulsatility in fetal systemic veins significantly correlated to the cardiac secretion of ANP. Fetal myocardial compromise resulted in a distribution of cardiac output toward the left ventricle and a rise in the right-ventricular afterload, explaining the increase in ANP (38). Seong et al., in a study to evaluate the relationship between NT-proBNP levels and the method of delivery, found that infants with low Apgar scores and low umbilical cord blood $\mathrm{pH}$ appeared to have increased levels of NT-proBNP (18). Elevation in cardiac troponin levels is much less common in the perinatal period. Tocolytic therapy with $\beta$-sympathomimetics was related to an elevation in cTnT in the neonate (39). Elevated levels of cTnT were found in infants born to mothers who experienced preeclampsia, thereby associating maternal disease with neonatal myocyte compromise (40). Makikallio et al. found that cTnT levels were elevated in infants born after severe placental insufficiency, although other studies failed to show an increase in cTnI levels during intrauterine growth restriction $(35,41)$.

Elevation in the levels of natriuretic peptides and troponins in the immediate postnatal period needs further study. It remains to be investigated whether these are a result of cardiac compromise or of postnatal adaptation. Furthermore, it remains to be investigated whether these findings add to information that is already clinically available and whether they are clinically discernible from perinatal complications such as perinatal asphyxia. Studies considering the use of cardiac markers in the immediate postnatal period must take into account elevated levels, as they might lead to misinterpretation.

Perinatal asphyxia. There are a limited number of studies of the role of natriuretic peptides in identifying cardiac compromise after perinatal asphyxia. A study by Carbonell et al. showed that infants experiencing neonatal encephalopathy maintained elevated ANP levels as compared with healthy infants, suggesting compromise of cardiac function. Plasma NT-proBNP levels were higher in neonates with hypoxiaischemia-induced encephalopathy complicated by myocardial ischemic injury (42).

We conducted a study to compare the roles of cardiac biomarkers in infants with neonatal encephalopathy receiving hypothermia treatment after a possible ischemic event and those not receiving such treatment. BNP levels decreased significantly during hypothermia treatment and were significantly lower at $48 \mathrm{~h}$ after birth and after rewarming in these infants as compared with infants who did not receive hypothermia treatment. This suggests cardiac adaptation during 
treatment with hypothermia and possibly a protective effect on cardiac function (43).

Troponins appear in the blood 2-4 $\mathrm{h}$ after perinatal asphyxia and consequent myocardial compromise, and remain detectable for up to $21 \mathrm{~d}$ (44). Much research has been done to evaluate the predictive value of cord blood cardiac troponins $(1,22)$. Möller et al. showed that cTnT had a high positive predictive value in the postnatal diagnosis of perinatal asphyxia (45). Szymankiewicz et al. determined cTnT levels at 12 and $24 \mathrm{~h}$ after birth in infants who had experienced asphyxia and those who had not. The authors of that study found cTnT to be the most useful tool for assessing myocardial injury. In their study, echocardiography appeared to be of less value, apart from its help in the frequent diagnosis of tricuspid insufficiency, reported earlier as being more common in newborns who had experienced asphyxia (46). However, Costa et al. did report such a relationship between higher cTnT levels and echocardiographic signs of myocardial compromise in infants who had experienced asphyxia. In newborns with echocardiographic signs of myocardial compromise (diminished left-ventricular output and stroke volume), $c \operatorname{TnT}$ levels were found to be more elevated (47). The effect of hypothermia on cardiac function has not been established, although the results of studies investigating the role of troponin in animals suggest that hypothermia treatment may have a protective effect (48). In a study by our group, no difference was found between cTnI levels in infants treated with hypothermia and those not treated with hypothermia (43). This was also the finding of Shastri et al., who compared cTnI levels at $48 \mathrm{~h}$ after birth. Possibly this finding is related to the relative differences in the timing of the hypoxic incident in the prenatal period (49).

The levels of cTnT and cTnI are related to the severity of perinatal hypoxia-ischemia $(49,50)$. In adult medicine, cardiac troponin levels are used to predict adverse outcomes in patients admitted to intensive care, even in those not presenting with myocardial injury. However, unlike in the adult population, circulatory failure is not a common cause of adverse outcomes in newborn infants $(51,52)$. Boo et al. did find that cTnT levels were significantly higher in infants who did not go on to survive, thereby suggesting that cardiac troponins can be used to predict short-term outcomes as well as longterm prognosis (53). Kanik et al. reported that survivors of neonatal encephalopathy had significantly lower cTnI levels at days 1 and 3 (54).

Cardiac troponins are used as markers of myocardial ischemia-induced injury. There is only limited research evidence identifying these biomarkers as indicators of clinically relevant postnatal circulatory compromise. It is possible that, even when biochemical signs of myocardial damage are present, the damage in most infants is not severe enough to be of clinical significance. Troponin levels are used as prognosticators after perinatal asphyxia; however, this remains only a surrogate marker of cerebral damage.

Patent ductus arteriosus. Given the pathophysiologic basis of a hemodynamically significant patent ductus arteriosus (hsPDA), natriuretic peptides, with their physiologic role, are candidates to be used as biomarkers in the identification of and treatment of this condition. hsPDA causes leftatrial and, subsequently, left-ventricular overload, leading to increased production of BNP and NT-proBNP. Several studies have proposed that natriuretic peptides may have a role as an additional diagnostic tool in hsPDA identification, with various cut-off values (Table 1) (5,20,55-60). Associations were found between natriuretic peptide levels and each of the following: ductal size, magnitude of shunting, and left-atrial to aorta root ratio $(5,59)$. BNP levels were found to be correlated with hemodynamic alterations caused by ductal size, constriction, and dilatation $(13,20,60)$. However, because of the high degree of variability, BNP measurements are not clinically useful for predicting changes in shunt magnitude (61). It would be of greater interest if natriuretic peptide levels could be useful in predicting responsiveness to treatment. In a study performed by Hammerman et al., NT-proBNP was not sensitive enough to predict ductal responsiveness to therapy. The difference between estimates of successful and unsuccessful closure was too small to be clinically relevant (62). Hsu et al. used BNP to predict the responsiveness of hsPDA to indomethacine. It was found that elevated levels of BNP ( $>522 \mathrm{pmol} / \mathrm{l})$ predicted nonresponsiveness with high sensitivity (88\%) and high specificity (87\%) (63). After

Table 1. Natriuretic peptides in identification of hemodynamically significant PDA (hsPDA)

\begin{tabular}{|c|c|c|c|c|c|c|}
\hline Gestational age & Included/hsPDA ( $n$ ) & Proposed cut-off value & Day & Sensitivity & Specificity & Reference \\
\hline$<28 \mathrm{Wk}$ & $67 / 24$ & $159 \mathrm{pmol} / \mathrm{l}(\mathrm{BNP})$ & 2 & $83 \%$ & $86 \%$ & 5 \\
\hline$<36 \mathrm{Wk}$ & $20 / 20$ & $88 \mathrm{pmol} / \mathrm{l}(\mathrm{BNP})$ & $>2$ & $-^{\mathrm{a}}$ & 一 $^{\mathrm{a}}$ & 20 \\
\hline$<34 \mathrm{Wk}$ & $29 / 14$ & $20 \mathrm{pmol} / \mathrm{l}(\mathrm{BNP})$ & 7 (median) & $93 \%$ & $73 \%$ & 55 \\
\hline$<34 \mathrm{Wk}$ & $66 / 23$ & $320 \mathrm{pmol} / \mathrm{l}(\mathrm{BNP})$ & 3 & $100 \%$ & $95 \%$ & 59 \\
\hline$<34 \mathrm{Wk}$ & $49 / 18$ & 1,345 pmol/I (NT-proBNP) & 3 & $100 \%$ & $95 \%$ & 54 \\
\hline$<33 \mathrm{Wk}$ & $35 / 12$ & 1,202 pmol/I (NT-proBNP) & 2 & $100 \%$ & $91 \%$ & 56 \\
\hline$<33 \mathrm{Wk}$ & $56 / 20$ & 2,850 pmol/I (NT-proBNP) & 3 & $90 \%$ & $89 \%$ & 57 \\
\hline$<30 \mathrm{Wk}$ & $48 / 25$ & 5,000 pmol/l (NT-proBNP) & 3 & $70 \%$ & $87 \%$ & 58 \\
\hline
\end{tabular}

BNP, B-type natriuretic peptide; hsPDA, hemodynamically significant patent ductus arteriosus; NT-proBNP, N-terminal fragment of BNP.

an the absence of control patients, no sensitivity and specificity could be calculated for hsPDA. 
successful treatment of an hsPDA, either noninvasively or surgically, NT-proBNP and BNP levels decrease as expected. The unresolved question is whether, during treatment with indomethacine, there is any additional value in using natriuretic peptides as markers over and above repeated echocardiographic evaluation. Attridge et al. found that, when BNP was used as an indicator, the number of indomethacine doses during the first course of treatment was reduced; however, the total number of indomethacine doses remained unaltered (3). Two studies by El-Khuffash et al. evaluated NT-proBNP levels in preterm infants with hsPDA as a predictor of longterm outcome. In these two studies, NT-proBNP and cTnT were used as markers to identify infants with hsPDA at risk of death before discharge and those at risk of severe intraventricular hemorrhage (grade III/IV). The infants with an hsPDA at $48 \mathrm{~h}$ after birth who subsequently died or developed severe intraventricular hemorrhage were compared with those who did not die or develop severe intraventricular hemorrhage. Although no differences were found in echocardiographic hsPDA characteristics, the levels of cTnT and NT-proBNP were significantly higher in infants at risk for an adverse outcome (64). In a follow-up study the same authors showed that NT-proBNP, in conjunction with cTnT and an hsPDA scoring system based on six echocardiographic criteria related to the hemodynamic significance of the hsPDA at $48 \mathrm{~h}$, could be used for the identification of infants at greatest risk of poor neurodevelopmental outcome (4).

An hsPDA can lead to stealing of coronary arterial blood flow, potentially leading to ischemia of the myocardium and elevation of cardiac troponin levels (65). Studies investigating the value of troponins as indicators of myocardial compromise showed no equivocal results $(66,67)$.It is therefore unlikely that myocardial compromise as signaled by troponin levels is of clinical significance (4).

The identification of an hsPDA in the clinical setting can be difficult, often calling for repeated echocardiographic measurements. Biological markers may facilitate the diagnosis. Elevated levels of BNP and NT-proBNP at day 3 can be used to identify an hsPDA. However, to validate the role of natriuretic peptides as markers in hsPDA treatment, a large prospective study is needed. Further investigation is required to determine whether biomarker-guided treatment protocols will improve short- and long-term outcomes for hsPDA as compared with current diagnostic protocols.

Persistent pulmonary hypertension. Persistent pulmonary hypertension of the neonate (PPHN) is a severe disease seen mostly in term infants. Because PPHN is usually associated with conditions affecting pulmonary function (sepsis, meconium aspiration, asphyxia), it is often difficult to arrive at an early diagnosis of PPHN, especially when echocardiographic evaluation is not available. BNP is used as a biomarker in the diagnosis and management of pulmonary hypertension (PH) in pediatric patients, and has been shown to have prognostic value. It has been suggested that, in PH, changes in BNP levels are of more importance than elevated levels alone (68). BNP levels have also been used to identify PPHN; Reynolds et al. showed that an initial BNP level of $>159 \mathrm{pmol} / \mathrm{l}$ has a specificity of $90 \%$ and a sensitivity of $100 \%$ in predicting PPHN. They reported (as our group also did in its study) a strong relationship between BNP and echocardiographic signs of increased pulmonary vascular resistance $(69,70)$. With BNP and NT-proBNP being suggested as screening biomarkers, it is important to realize that congenital heart defects can also present themselves with PPHN and elevated BNP levels (71). A finding of BNP elevation should therefore prompt additional cardiologic evaluation in high-risk infants. Apart from identifying elevated pulmonary vascular resistance, BNP levels can be used to monitor the response to treatment. We investigated the use of BNP as a biomarker in the treatment of PPHN. In infants treated with nitric oxide, a decrease in BNP was found after initiation of treatment. However, where there is a sharp increase during cessation or weaning of nitric oxide, one should suspect a rebound; our study showed that an increase in BNP levels preceded the onset of clinical signs of a "rebound" PPHN (70).

The studies described here suggest a role for natriuretic peptides in the diagnosis and treatment of PPHN; however, the role of troponins is less clear. Torbicki et al. studied cTnT as an independent marker of increased mortality risk in adult patients with chronic precapillary $\mathrm{PH}$. The results suggested a relationship between right-ventricular dysfunction and cTnI levels. However, similar studies have not been carried out in infants (72). Validation is needed before these cardiac biomarkers can be used in clinical practice. Prospective studies are needed to determine whether natriuretic peptides can be used to predict outcomes in patients with PPHN.

Bronchopulmonary dysplasia. In "new bronchopulmonary dysplasia" (BPD), pulmonary arterial hypertension (PAH) occurs in infants who are more severely affected (73). Given that a reduction in arterial development coincides with the occurrence of $\mathrm{BPD}$ and $\mathrm{PAH}$, it can be assumed that there is a reduction in the development of the pulmonary arteries in these infants (74). Right-ventricular changes occur as a result of changes in pulmonary structure and function. In addition, systemic hypertension and the use of steroids to treat BPD may lead to left-ventricular dysfunction, further exacerbating PAH (75). Echocardiography and cardiac catheterization are labor- and time-intensive, and their interpretation depends on the experience of the investigator. There is therefore a need for a reliable and easy screening method. Ventricular dysfunction as a result of PAH in a patient with BPD may lead to increases in the levels of BNP or NT-proBNP, thereby making them possible screening tools under these conditions. An observational study found that NT-proBNP levels showed elevated values corresponding to the severity of BPD; however, no evidence of ventricular dysfunction or pulmonary hypertension was found in the infants studied (76). To our knowledge, there have been no subsequent studies to investigate the use of natriuretic peptides as biomarkers in BPD. Given the underlying pathophysiologic principle and 
Table 2. Conditions affecting newborn infants and the effect on cardiac biomarkers troponin (cTnl and cTnT) and BNP (and NT-proBNP)

\begin{tabular}{|c|c|c|c|c|c|}
\hline \multirow[b]{2}{*}{ Condition } & \multicolumn{2}{|c|}{ BNP } & \multicolumn{2}{|c|}{ Troponin } & \multirow[b]{2}{*}{ Clinical relevance } \\
\hline & Premature & Term & Premature & Term & \\
\hline IRDS & $\Uparrow$ & & $\Uparrow$ & & Not known \\
\hline Sepsis/NEC & $\Uparrow$ & $=/ \Uparrow$ & $=/ \Uparrow$ & $=/ \Uparrow$ & Not known \\
\hline PPHN & $\Uparrow$ & $\Uparrow$ & & & Diagnosis and possibly therapy \\
\hline Growth retardation & $\Uparrow$ & & $=/ \Uparrow$ & & Not known \\
\hline Preeclampsia & $=/ \Uparrow$ & & $\Uparrow$ & & Not known \\
\hline BPD & $\Uparrow$ & $\Uparrow$ & & & Not known \\
\hline
\end{tabular}

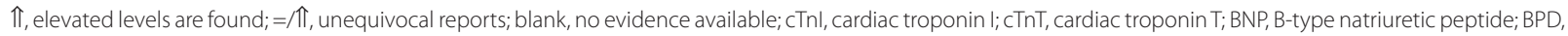

bronchopulmonary dysplasia; IRDS, infant respiratory distress syndrome; NEC, necrotizing enterocolitis; NT-proBNP, N-terminal fragment of BNP; PDA, patent ductus arteriosus; PPHN persistent pulmonary hypertension of the newborn.

the importance of having an easy screening tool for $\mathrm{PAH}$ in $\mathrm{BPD}$, further research is needed.

Sepsis. Investigations have shown that BNP levels are elevated in adult patients with severe sepsis and shock. The levels appeared to be comparable to those found in adults with acute heart failure (77). How inflammation and myocardial dysfunction during sepsis are related to BNP levels has yet to be determined, although cardiac dysfunction is common in patients with severe sepsis or septic shock. A study by Domico et al. in children ranging in age from $2 \mathrm{wk}$ to $18 \mathrm{y}$ showed elevated BNP levels in septic shock. BNP levels at $12 \mathrm{~h}$ after birth correlated well with disease severity and myocardial dysfunction (78). Clark et al. found that the cTnT levels were significantly higher in sick infants than in healthy ones. The use of inotropic support and oxygen requirement were independently associated with higher cTnT levels (79).

The validation of cardiac biological markers for sepsis in newborn infants is a complex task, especially in preterm infants in whom different causes for impaired cardiac function often coincide. Currently, there is no evidence to promote the routine use of cardiac biomarkers for this indication.

Future directions. Research on cardiac biomarkers and their clinical implications has intensified significantly in the past few years. Several possible clinical implications have been suggested, and these are summarized in Table 2. A first step before cardiac biomarkers can be introduced into routine care is the establishment of unambiguous normal ranges. Although efforts in this direction have been made, the variability in the assays used and in local conditions make comparison of study results difficult. However, as earlier stated, the increase in the use of cardiac biomarkers, the emphasis on the need to generate normal ranges, standardization of methods, and increased commercial availability, possibly in combination with a "point-of-care" facility, should help to overcome this problem. Studies have suggested that natriuretic peptides can be used as biomarkers in the identification and treatment of hsPDA and PPHN, and that troponins can find similar use in the identification of cardiac compromise in infants after perinatal asphyxia and neonatal encephalopathy.
Another important step should be to validate these biomarkers in the populations of interest, where current evidence is most promising. This will determine whether therapy guided by these biomarkers will improve treatment outcomes.

\section{CONCLUSIONS}

The levels of natriuretic peptides and troponins are currently used in clinical practice to assess changes in cardiac function and cardiomyocyte compromise. This review shows that perinatal adaptations as well as diseases commonly affecting newborn infants influence the levels of these biomarkers. Currently there is insufficient evidence to promote the routine clinical use of these cardiac biomarkers in newborns. We therefore conclude that, although natriuretic peptides and cardiac troponins provide the possibility to better evaluate cardiocirculatory compromise in infants, the establishment of reliable normal ranges in the early newborn period and the validation of these biomarkers in a population of interest are the necessary first steps before routine clinical use can be advocated.

\section{STATEMENT OF FINANCIAL SUPPORT}

No financial assistance was received in support of this study.

\section{REFERENCES}

1. Trevisanuto D, Picco G, Golin R, et al. Cardiac troponin I in asphyxiated neonates. Biol Neonate 2006;89:190-3.

2. El-Khuffash A, Davis PG, Walsh K, Molloy EJ. Cardiac troponin T and N-terminal-pro-B type natriuretic peptide reflect myocardial function in preterm infants. J Perinatol 2008;28:482-6.

3. Attridge JT, Kaufman DA, Lim DS. B-type natriuretic peptide concentrations to guide treatment of patent ductus arteriosus. Arch Dis Child Fetal Neonatal Ed 2009;94:F178-82.

4. El-Khuffash AF, Slevin M, McNamara PJ, Molloy EJ. Troponin T, N-terminal pro natriuretic peptide and a patent ductus arteriosus scoring system predict death before discharge or neurodevelopmental outcome at 2 years in preterm infants. Arch Dis Child Fetal Neonatal Ed 2011;96:F133-7.

5. Czernik C, Lemmer J, Metze B, Koehne PS, Mueller C, Obladen M. B-type natriuretic peptide to predict ductus intervention in infants $<28$ weeks. Pediatr Res 2008;64:286-90.

6. El-Khuffash A, Molloy EJ. Are B-type natriuretic peptide (BNP) and N-terminal-pro-BNP useful in neonates? Arch Dis Child Fetal Neonatal Ed 2007;92:F320-4.

7. de Bold AJ, Borenstein HB, Veress AT, Sonnenberg H. A rapid and potent natriuretic response to intravenous injection of atrial myocardial extract in rats. Life Sci 1981;28:89-94. 
8. Schweitz H, Vigne P, Moinier D, Frelin C, Lazdunski M. A new member of the natriuretic peptide family is present in the venom of the green mamba (Dendroaspis angusticeps). J Biol Chem 1992;267:13928-32.

9. Woodard GE, Rosado JA, Brown J. Expression and control of C-type natriuretic peptide in rat vascular smooth muscle cells. Am J Physiol Regul Integr Comp Physiol 2002;282:R156-65.

10. Suttner SW, Boldt J. Natriuretic peptide system: physiology and clinical utility. Curr Opin Crit Care 2004;10:336-41.

11. Doust JA, Glasziou PP, Pietrzak E, Dobson AJ. A systematic review of the diagnostic accuracy of natriuretic peptides for heart failure. Arch Intern Med 2004;164:1978-84.

12. Mir TS, Laux R, Hellwege HH, et al. Plasma concentrations of aminoterminal pro atrial natriuretic peptide and aminoterminal pro brain natriuretic peptide in healthy neonates: marked and rapid increase after birth. Pediatrics 2003;112:896-9.

13. Holmström H, Hall C, Thaulow E. Plasma levels of natriuretic peptides and hemodynamic assessment of patent ductus arteriosus in preterm infants. Acta Paediatr 2001;90:184-91.

14. Breuer T, Sápi E, Skoumal R, et al. N-terminal probrain natriuretic peptide level inversely correlates with cardiac index after arterial switch operation in neonates. Paediatr Anaesth 2007;17:782-8.

15. Nir A, Lindinger A, Rauh M, et al. NT-pro-B-type natriuretic peptide in infants and children: reference values based on combined data from four studies. Pediatr Cardiol 2009;30:3-8.

16. Mannarino S, Garofoli F, Mongini E, et al. BNP concentrations and cardiovascular adaptation in preterm and fullterm newborn infants. Early Hum Dev 2010;86:295-8.

17. Gemelli M, Mamì C, Manganaro R, Stelitano L, Bonaccorsi P, Martino F. Effects of the mode of delivery on ANP and renin-aldosterone system in the fetus and the neonate. Eur J Obstet Gynecol Reprod Biol 1992;43:181-4.

18. Seong WJ, Yoon DH, Chong GO, et al. Umbilical cord blood amino-terminal pro-brain natriuretic peptide levels according to the mode of delivery. Arch Gynecol Obstet 2010;281:907-12.

19. Fortunato G, Carandente Giarrusso P, Martinelli P, et al. Cardiac troponin $\mathrm{T}$ and amino-terminal pro-natriuretic peptide concentrations in fetuses in the second trimester and in healthy neonates. Clin Chem Lab Med 2006;44:834-6.

20. Flynn PA, da Graca RL, Auld PA, Nesin M, Kleinman CS. The use of a bedside assay for plasma B-type natriuretic peptide as a biomarker in the management of patent ductus arteriosus in premature neonates. J Pediatr 2005;147:38-42.

21. Omokhodion SI, Losekoot TG, Jaiyesimi F. Serum creatine kinase and creatine kinase-MB isoenzyme activities in perinatally asphyxiated newborns. Eur Heart J 1991;12:980-4.

22. Türker G, Babaoglu K, Gökalp AS, Sarper N, Zengin E, Arisoy AE. Cord blood cardiac troponin I as an early predictor of short-term outcome in perinatal hypoxia. Biol Neonate 2004;86:131-7.

23. Wu AH, Apple FS, Gibler WB, Jesse RL, Warshaw MM, Valdes R Jr. National Academy of Clinical Biochemistry Standards of Laboratory Practice: recommendations for the use of cardiac markers in coronary artery diseases. Clin Chem 1999;45:1104-21.

24. Anderson PA, Malouf NN, Oakeley AE, Pagani ED, Allen PD. Troponin $\mathrm{T}$ isoform expression in humans. A comparison among normal and failing adult heart, fetal heart, and adult and fetal skeletal muscle. Circ Res 1991;69:1226-33.

25. Gaze DC, Collinson PO. Cardiac troponin I should be interpreted with caution in paediatric neonatal patients. Concerning Turker et al.: 'Cord blood cardiac troponin I as an early predictor of short-term outcome in perinatal hypoxia. Biol Neonate 2005;87:19.

26. Iacovidou N, Boutsikou M, Gourgiotis D, et al. Perinatal changes of cardiac troponin-I in normal and intrauterine growth-restricted pregnancies. Mediators Inflamm 2007;2007:53921.

27. Trevisanuto D, Doglioni N, Altinier S, Zaninotto M, Plebani M, Zanardo V. Cardiac troponin I at birth is of fetal-neonatal origin. Arch Dis Child Fetal Neonatal Ed 2009;94:F464-6.

28. Shelton SD, Fouse BL, Holleman CM, Sedor FA, Herbert WN. Cardiac troponin T levels in umbilical cord blood. Am J Obstet Gynecol 1999;181(5 Pt 1):1259-62.
29. Bodor GS, Porterfield D, Voss EM, Smith S, Apple FS. Cardiac troponin-I is not expressed in fetal and healthy or diseased adult human skeletal muscle tissue. Clin Chem 1995;41(12 Pt 1):1710-5.

30. Sasse S, Brand NJ, Kyprianou P, et al. Troponin I gene expression during human cardiac development and in end-stage heart failure. Circ Res 1993;72:932-8.

31. El-Khuffash AF, Molloy EJ. Serum troponin in neonatal intensive care. Neonatology 2008;94:1-7.

32. Trevisanuto D, Zaninotto M, Altinier S, Plebani M, Zanardo V. High serum cardiac troponin $\mathrm{T}$ concentrations in preterm infants with respiratory distress syndrome. Acta Paediatr 2000;89:1134-6.

33. Clark SJ, Newland P, Yoxall CW, Subhedar NV. Cardiac troponin T in cord blood. Arch Dis Child Fetal Neonatal Ed 2001;84:F34-7.

34. McAuliffe F, Mears K, Fleming S, Grimes H, Morrison JJ. Fetal cardiac troponin I in relation to intrapartum events and umbilical artery $\mathrm{pH}$. Am J Perinatol 2004;21:147-52.

35. Crispi F, Hernandez-Andrade E, Pelsers MM, et al. Cardiac dysfunction and cell damage across clinical stages of severity in growth-restricted fetuses. Am J Obstet Gynecol 2008;199:254.e1-8.

36. Girsen A, Ala-Kopsala M, Mäkikallio K, Vuolteenaho O, Räsänen J. Cardiovascular hemodynamics and umbilical artery $\mathrm{N}$-terminal peptide of proB-type natriuretic peptide in human fetuses with growth restriction. Ultrasound Obstet Gynecol 2007;29:296-303.

37. Crispi F, Comas M, Hernández-Andrade E, et al. Does pre-eclampsia influence fetal cardiovascular function in early-onset intrauterine growth restriction? Ultrasound Obstet Gynecol 2009;34:660-5.

38. Mäkikallio K, Vuolteenaho O, Jouppila P, Räsänen J. Ultrasonographic and biochemical markers of human fetal cardiac dysfunction in placental insufficiency. Circulation 2002;105:2058-63.

39. Adamcová M, Kokstein Z, Palicka V, Vávrová J, Podholová M, Kostál M. Cardiac troponin $\mathrm{T}$ in neonates after acute and long-term tocolysis. Biol Neonate 2000;78:288-92.

40. Karadeniz L, Coban A, Ince Z, Turkoglu U, Can G. Cord blood cardiac troponin $\mathrm{T}$ and nonprotein-bound iron levels in newborns of mild preeclamptic mothers. Neonatology 2010;97:305-10.

41. Mäkikallio K, Vuolteenaho O, Jouppila P, Räsänen J. Association of severe placental insufficiency and systemic venous pressure rise in the fetus with increased neonatal cardiac troponin T levels. Am J Obstet Gynecol 2000;183:726-31.

42. Zhang ZL, Lin LX, An CX, Tao ZB, Yang M. [Changes of N-terminal probrain natriuretic peptide in neonates with myocardial ischemic injury]. Zhongguo Dang Dai Er Ke Za Zhi 2009;11:973-5.

43. Vijlbrief DC, Benders MJNL, Kemperman H, et al. Cardiac biomarkers as indicators of hemodynamic adaptation during postasphyxial hypothermia treatment. Neonatology 2012;102:243-8 (doi: 10.1159/ 000339117).

44. Bertinchant JP, Larue C, Pernel I, et al. Release kinetics of serum cardiac troponin I in ischemic myocardial injury. Clin Biochem 1996;29:587-94.

45. Möller JC, Thielsen B, Schaible TF, et al. Value of myocardial hypoxia markers (creatine kinase and its MB-fraction, troponin-T, QT-intervals) and serum creatinine for the retrospective diagnosis of perinatal asphyxia. Biol Neonate 1998;73:367-74.

46. Szymankiewicz M, Matuszczak-Wleklak M, Hodgman JE, Gadzinowski J. Usefulness of cardiac troponin $\mathrm{T}$ and echocardiography in the diagnosis of hypoxic myocardial injury of full-term neonates. Biol Neonate 2005;88:19-23.

47. Costa $\mathrm{S}$, Zecca E, De Rosa $\mathrm{G}$, et al. Is serum troponin $\mathrm{T}$ a useful marker of myocardial damage in newborn infants with perinatal asphyxia? Acta Paediatr 2007;96:181-4.

48. Liu X, Tooley J, Løberg EM, Suleiman MS, Thoresen M. Immediate hypothermia reduces cardiac troponin I after hypoxic-ischemic encephalopathy in newborn pigs. Pediatr Res 2011;70:352-6.

49. Shastri AT, Samarasekara S, Muniraman H, Clarke P. Cardiac troponin I concentrations in neonates with hypoxic-ischaemic encephalopathy. Acta Paediatr 2012;101:26-9.

50. Günes T, Oztürk MA, Köklü SM, Narin N, Köklü E. Troponin-T levels in perinatally asphyxiated infants during the first 15 days of life. Acta Paediatr 2005;94:1638-43. 


\section{Cardiac biomarkers in neonatology}

51. King DA, Codish S, Novack V, Barski L, Almog Y. The role of cardiac troponin I as a prognosticator in critically ill medical patients: a prospective observational cohort study. Crit Care 2005;9:R390-5.

52. Evers AC, van Leeuwen J, Kwee A, et al. [Mortality and morbidity among full-term neonates in a neonatal intensive care unit in the Utrecht region, the Netherlands]. Ned Tijdschr Geneeskd 2010;154:A118.

53. Boo NY, Hafidz H, Nawawi HM, et al. Comparison of serum cardiac troponin $\mathrm{T}$ and creatine kinase $\mathrm{MB}$ isoenzyme mass concentrations in asphyxiated term infants during the first $48 \mathrm{~h}$ of life. J Paediatr Child Health 2005;41:331-7.

54. Kanik E, Ozer EA, Bakiler AR, et al. Assessment of myocardial dysfunction in neonates with hypoxic-ischemic encephalopathy: is it a significant predictor of mortality? J Matern Fetal Neonatal Med 2009;22:239-42.

55. Farombi-Oghuvbu I, Matthews T, Mayne PD, Guerin H, Corcoran JD. $\mathrm{N}$-terminal pro-B-type natriuretic peptide: a measure of significant patent ductus arteriosus. Arch Dis Child Fetal Neonatal Ed 2008;93:F257-60.

56. Sanjeev S, Pettersen M, Lua J, Thomas R, Shankaran S, L'Ecuyer T. Role of plasma B-type natriuretic peptide in screening for hemodynamically significant patent ductus arteriosus in preterm neonates. J Perinatol 2005;25:709-13.

57. Nuntnarumit $P$, Khositseth A, Thanomsingh P. N-terminal probrain natriuretic peptide and patent ductus arteriosus in preterm infants. J Perinatol 2009;29:137-42.

58. Ramakrishnan S, Heung YM, Round J, Morris TP, Collinson P, Williams AF. Early N-terminal pro-brain natriuretic peptide measurements predict clinically significant ductus arteriosus in preterm infants. Acta Paediatr 2009;98:1254-9.

59. El-Khuffash AF, Amoruso M, Culliton M, Molloy EJ. N-terminal pro-Btype natriuretic peptide as a marker of ductal haemodynamic significance in preterm infants: a prospective observational study. Arch Dis Child Fetal Neonatal Ed 2007;92:F421-2.

60. Choi BM, Lee KH, Eun BL, et al. Utility of rapid B-type natriuretic peptide assay for diagnosis of symptomatic patent ductus arteriosus in preterm infants. Pediatrics 2005;115:e255-61.

61. Chen S, Tacy T, Clyman R. How useful are B-type natriuretic peptide measurements for monitoring changes in patent ductus arteriosus shunt magnitude? J Perinatol 2010;30:780-5.

62. Hammerman C, Shchors I, Schimmel MS, Bromiker R, Kaplan M, Nir A. N-terminal-pro-B-type natriuretic peptide in premature patent ductus arteriosus: a physiologic biomarker, but is it a clinical tool? Pediatr Cardiol 2010;31:62-5.

63. Hsu JH, Yang SN, Chen HL, Tseng HI, Dai ZK, Wu JR. B-type natriuretic peptide predicts responses to indomethacin in premature neonates with patent ductus arteriosus. J Pediatr 2010;157:79-84.

64. El-Khuffash A, Barry D, Walsh K, Davis PG, Molloy EJ. Biochemical markers may identify preterm infants with a patent ductus arteriosus at high risk of death or severe intraventricular haemorrhage. Arch Dis Child Fetal Neonatal Ed 2008;93:F407-12.
65. McNamara PJ, Sehgal A. Towards rational management of the patent ductus arteriosus: the need for disease staging. Arch Dis Child Fetal Neonatal Ed 2007;92:F424-7.

66. El-Khuffash AF, Molloy EJ. Influence of a patent ductus arteriosus on cardiac troponin T levels in preterm infants. J Pediatr 2008;153:350-3.

67. Trevisanuto D, Zaninotto M, Lachin M, et al. Effect of patent ductus arteriosus and indomethacin treatment on serum cardiac troponin $\mathrm{T}$ levels in preterm infants with respiratory distress syndrome. Eur J Pediatr 2000;159:273-6.

68. Bernus A, Wagner BD, Accurso F, Doran A, Kaess H, Ivy DD. Brain natriuretic peptide levels in managing pediatric patients with pulmonary arterial hypertension. Chest 2009;135:745-51.

69. Reynolds EW, Ellington JG, Vranicar M, Bada HS. Brain-type natriuretic peptide in the diagnosis and management of persistent pulmonary hypertension of the newborn. Pediatrics 2004;114:1297-304.

70. Vijlbrief DC, Benders MJ, Kemperman H, van Bel F, de Vries WB. B-type natriuretic peptide and rebound during treatment for persistent pulmonary hypertension. J Pediatr 2012;160:111-5.e1.

71. Nir A, Bar-Oz B, Perles Z, Brooks R, Korach A, Rein AJ. N-terminal pro-Btype natriuretic peptide: reference plasma levels from birth to adolescence. Elevated levels at birth and in infants and children with heart diseases. Acta Paediatr 2004;93:603-7.

72. Torbicki A, Kurzyna M, Kuca P, et al. Detectable serum cardiac troponin $\mathrm{T}$ as a marker of poor prognosis among patients with chronic precapillary pulmonary hypertension. Circulation 2003;108:844-8.

73. Kim GB. Pulmonary hypertension in infants with bronchopulmonary dysplasia. Korean J Pediatr 2010;53:688-93.

74. Farquhar M, Fitzgerald DA. Pulmonary hypertension in chronic neonatal lung disease. Paediatr Respir Rev 2010;11:149-53.

75. Mourani PM, Ivy DD, Rosenberg AA, Fagan TE, Abman SH. Left ventricular diastolic dysfunction in bronchopulmonary dysplasia. J Pediatr 2008;152:291-3.

76. Joseph L, Nir A, Hammerman C, Goldberg S, Ben Shalom E, Picard E. $\mathrm{N}$-terminal pro-B-type natriuretic peptide as a marker of bronchopulmonary dysplasia in premature infants. Am J Perinatol 2010;27:381-6.

77. Rudiger A, Gasser S, Fischler M, Hornemann T, von Eckardstein A, Maggiorini M. Comparable increase of B-type natriuretic peptide and amino-terminal pro-B-type natriuretic peptide levels in patients with severe sepsis, septic shock, and acute heart failure. Crit Care Med 2006;34:2140-4.

78. Domico M, Liao P, Anas N, Mink RB. Elevation of brain natriuretic peptide levels in children with septic shock. Pediatr Crit Care Med 2008;9:478-83.

79. Clark SJ, Newland P, Yoxall CW, Subhedar NV. Concentrations of cardiac troponin $\mathrm{T}$ in neonates with and without respiratory distress. Arch Dis Child Fetal Neonatal Ed 2004;89:F348-52. 